\title{
Military and Financial Expenses Commit Combat to COVID 19
}

\author{
José Menezes Gomes* \\ Professor of Economics at UFAL, Universidade Federal de Alagoas, Brazil
}

\begin{abstract}
This article deals with the relationship between the growing military and financial expenditures of the states and how this process led to the sacrifice of public policies, facilitating the spread of this pandemic throughout the world. All this results from the deepening of neoliberalism, which in a synchronized manner contributed to the process of privatization and dismantling of the public machinery. We point out that the wealthiest countries that have higher military spending experienced the highest number of deaths and infections. In this direction, we observe that the USA has the largest military expenditure on the planet, while the health sector is privatized, which makes it difficult to combat the covid 19. At the same time, we observe that part of the countries' public debt results from the effects of the 2008 crisis that used public money to save private enterprises while deepening the privatization of public services.
\end{abstract}

Keywords: COVID-19, Virus, Social welfare, Health insurance, Emergency medicine

\section{Introduction}

At this moment, marked by the occurrence of another stage of the capitalist crisis, where the emergence of the pandemic gives an even more dramatic outline than the crisis of 2008 , we have a great paradox: the richest nations in the world, the most armed and most indebted pass to be record holders of infection and death by COVID 19. Here we will see how the United States, which has the largest military budget on the planet and the largest number of military bases in the most varied countries, in addition to the dominance over the media of the world, while ranks first in deaths and in those infected by COVID $19 .{ }^{1}$ In the same direction, we have among the most developed countries in Europe a large space for the occurrence of deaths and infections. In the search for an explanation of this fact, we will add the austerity policy in the European Union and the process of commercialization of American health and limited labor rights, which prevent part of the population from having access to health treatment licenses. In addition, the delay in the application of the social isolation policy is added as a basis for combating the pandemic. In other words, we intend to show the class character of these states, especially in the USA, which drive huge military spending, while expanding cuts in social spending, which pave the way for the devastating effects of the pandemic, also compromising the reproduction of capital, since the world economy goes through a reduction in activity that can alter the time of capital rotation. In this sense, it is worth remembering that this virus started in China and quickly spread throughout the world, especially in countries that resisted putting social isolation into practice. However, the fight against the virus is not only done with the declaration of social isolation, but with the effectiveness of social policies, with emphasis on the public health policy adopted or not. In China, we had a combination of social isolation policy and public health policy, which ended up generating months of economic paralysis and rela-

${ }^{1}$ To see https://www.cadtm.org/As-nacoes-mais-ricas-mais-armadas-e-mais-endividadas-perdendo-a-guerra-para-um

Quick Response Code:

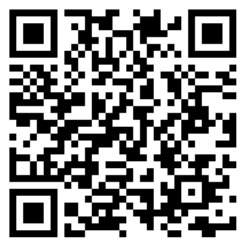

*Corresponding author: José Menezes Gomes, Professor of Economics at UFAL, Campus Sertão and the Graduate Program in Social Work, Universidade Federal de Alagoas, Coordinator of the Alagoas Nucleus for Citizen Audit and member of the Chairs Network on public debt, Brazil

Received: 22 January, 2021

Published: 26 March, 2021

Citation: José Menezes Gomes. Military and Financial Expenses Commit Combat to COVID 19. SOJ Complement Emerg Med. 2021;1(1):1-5. DOI: 10.53902/SOJCEM.2021.01.000503 
tive control of the pandemic, which resulted in a number of 81,953 infected and 3,350 dead (data from 11/04/2020) in a population of 1,400 million.China resumed activity in the first week of April, even with the risk of a new wave of contamination, while the other countries began to face the pandemic. The United States, which initially resisted the adoption of quarantine, takes first place in the death toll of $100,000,{ }^{2}$ at the end of May, of a total of 1.6 million infected people, even having tested 16 million inhabitants, out of a population of 329 million. In order to have a precise notion of the occurrence of contamination cases, on June 14, 2020, Graph 1 shows that developed countries, which were the main protagonists, maintained their participation, being the USA (27.15\%), United Kingdom (3 , 74\%), Spain (3.67\%), Italy (2.99\%), Germany (2.37\%) and France (1.98\%). Meanwhile, countries like Brazil (10.77\%), Russia (Russia (6.68\%), India (4.10\%) had growth in the most current phase of the pandemic Figure 1.

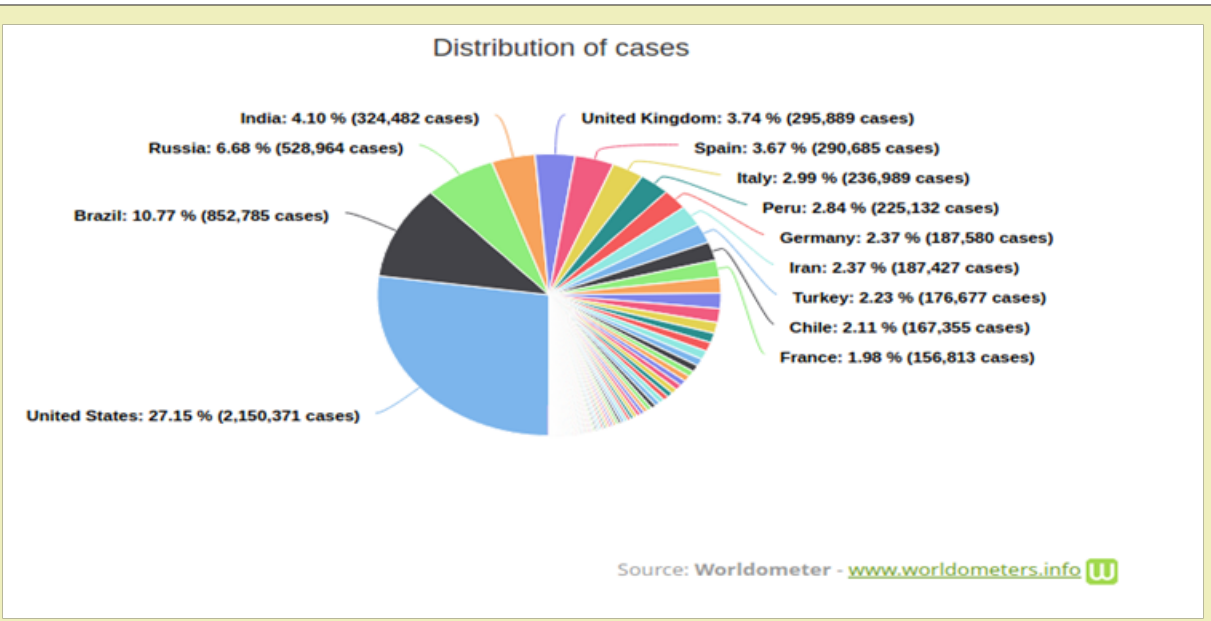

Figure 1: Distribution of COVID 19 cases worldwide.

\section{Development}

In the initial phase, we had the USA, Italy, Spain, France, the United Kingdom and Germany as the epicenter of the number of contaminated and dead people, followed by the occurrence of Brazil with the second largest case of contagion of 560 thousand and 32 thousand deaths in early June. Outside the developed country bloc, we also have Russia, which had 450,000 people infected, with the lowest number of deaths of 5,500, on the same date. It is worth remembering that the countries that were the main protagonists in the spread of COVID 19, were the same ones that during the glorious thirty years after the war experienced the Social Welfare State and are part of NATO (North Atlantic Treaty Organization). These are, therefore, countries where the productive forces were at the most developed stage and with progressive tax policies. In Figure 2 , we can see that on June 14,2020 , the total number of infected in 213 countries was 7,941,704, while 433,953 died with 4,068,249 recovered. Among these countries the highlights with the number of dead are the USA $(117,690)$, Brazil $(42,837)$, United Kingdom $(41,698)$, Italy $(34,345)$, France $(29,398)$, Spain $(27,136)$, Mexico $(16,872)$, Belgium $(9,655)$, Germany $(8,868)$ Canada $(8,146)$. Meanwhile, the most populous countries had a lower death toll such as China $(4,634)$ and India $(9,520)$.

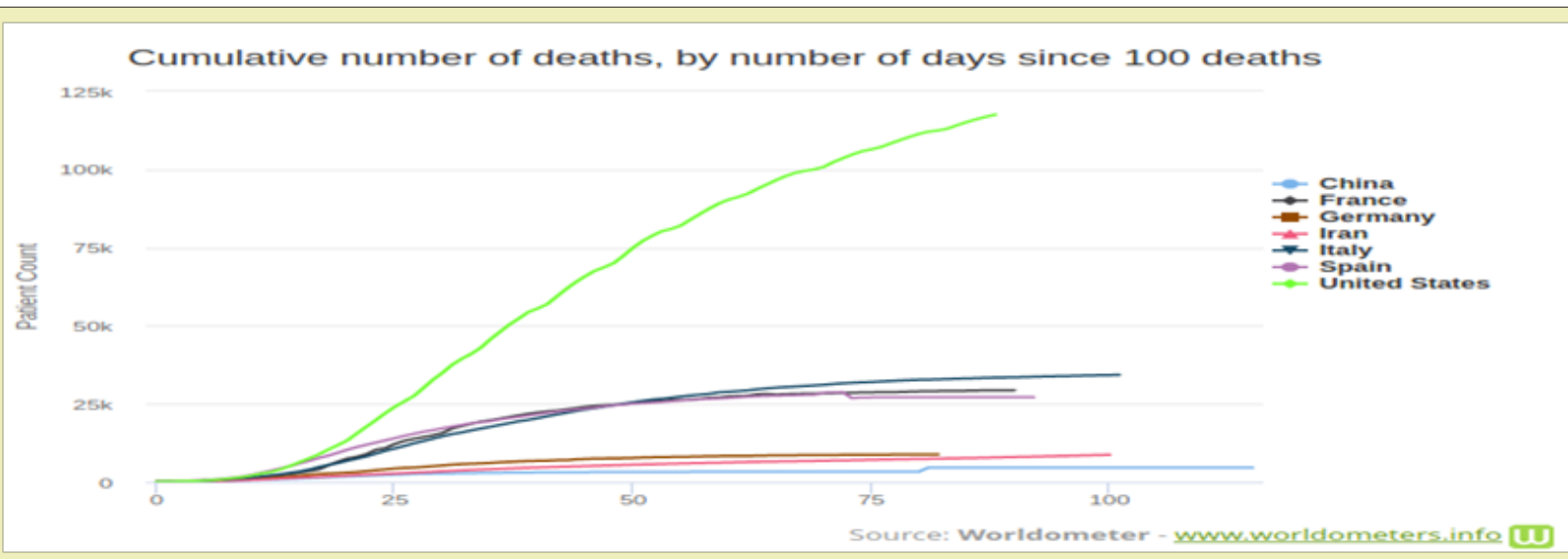

Figure 2: Accumulated number of deaths (by number of days since 100 deaths).

${ }^{2}$ The New York Times figures include data on nursing homes, assisted living facilities, memory care facilities, retirement and elderly communities, and rehabilitation facilities. To seehttps://oglobo.globo.com/sociedade/coronavirus/um-terco-das-mortes-por-covid-19-nos-eua-aconteceu-em-asilos-24424719 
Interestingly, among the hardest hit are not the most populous countries, but the countries that are part of the $G 7$, rich countries in the world and that together concentrate a large part of the world GDP and military spending and spending on public debt service. To try to understand this fact, we will first investigate the military spending of these countries or how they prioritize military spending and move away from social spending. Figure 2 shows the federal government's allocations in the USA, with great emphasis on spending on military expenditures, representing almost half of the budget. At the same time, the amount earmarked for servicing the public debt stands out. If we add military spending on public debt service, we will see that it is a much larger amount than that destined for social assistance, public administration, science, energy and the environment, public health, education and work and diplomacy. As for the amount allocated to health, it is worth remembering that it is not about investing in a public health system. Here the class character of that country is clear, since it prioritizes spending to maintain its war machine that drives the interest of its great monopolies around the world Figure 3.
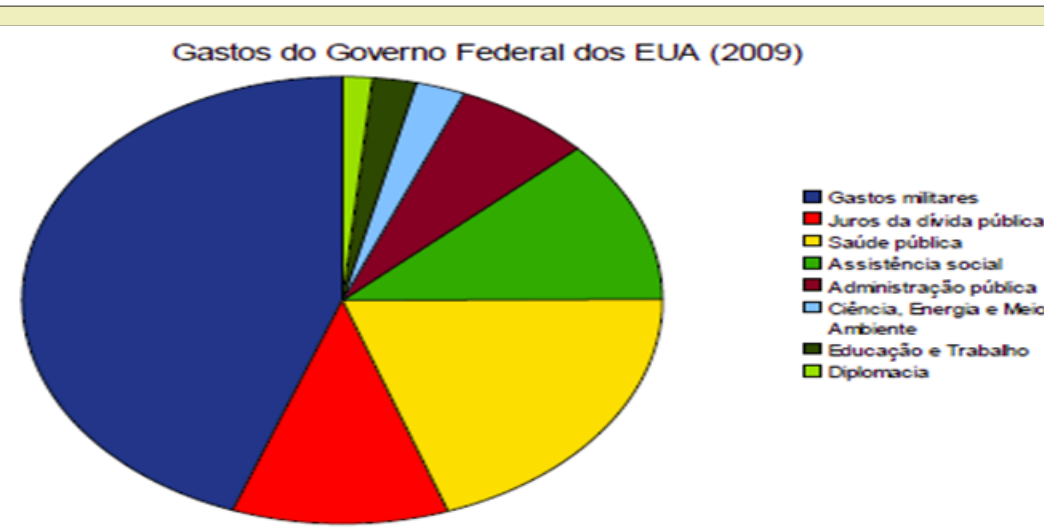

Figure 3: US Federal Government spending (2009).

Source: <http://caderno.allanpatrick.net/wp-content/uploads/2010/01/porque-contribuinte-eua-odeia-governo-federal.png>

The United States, which spends more than $\$ 700$ billion or $\mathrm{R}$ $\$ 3.6$ trillion a year on the military budget and spent trillions of dollars to save large companies and large banks in the 2008 crisis, has no desire to bank. a public health system, not even for 29 million Americans who do not have a private health insurance and who are even more vulnerable to the spread of this pandemic. ${ }^{3}$ Thus, with so many expenditures on armaments, the US vulnerability in the public health system ended up weakening even its gigantic War machine, as happened with the Nuclear Aircraft Carrier Theodore Roosevelt. ${ }^{4}$ At this time, 550 military personnel were contaminated and the Commander was removed from office, but applauded by the former commanders, for having authorized the immediate evacuation of all crew members. Such contamination also occurred in a French aircraft carrier, in the same period. It is worth remembering that this country, which is characterized by extreme neoliberalism and spends a large part of its budget on the arms race and the payment of debt service, the largest public debt in the world with $100 \%$ of its GDP, while allowing health be a big business, which compromises an effective fight against COVID 19.

At this point, it is important to ask whose service are these war machines, which can destroy the planet 17 times? In the develop- ment of capitalism, especially in the monopoly phase, we know that the respective war machines are at the service of the big monopoly corporations, which use their respective national states and public money to fight for the world market, while denying the majority of the population the rights more basic, especially in the neoliberal phase. In the American case, this war machine has always been in the organization and support of military coups, especially in Latin America, to impose governments committed to oppression within each country and to transfer the wealth extracted here to large monopoly groups.However, despite the G7 countries having a high military expenditure, this is a worldwide trend. According to the Stockholm International Peace Research Institute, worldwide military spending in 2015 was $\$ 1.7$ trillion or $\mathrm{R} \$ 8.5$ trillion. This figure was very close to the GDP of US $\$ 1.6$ trillion or $\mathrm{R} \$ 8.3$ billion, when Brazil was the sixth economy in the world. These figures refer to the annual sum of all that the countries spent not only on war and the acquisition of military material, but also on the maintenance of personnel - including pensions, which occupy a large part of military budgets. ${ }^{5}$ According to this same source, if these governments allocate $10 \%$ of annual military expenditures to fight poverty and hunger, the problems would be solved by 2030 , with the UN targets being reached. ${ }^{6}$

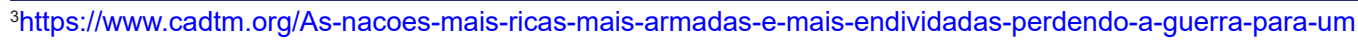

${ }^{4} \mathrm{https}$ //jornalaguaverde.com.br/capitao-do-porta-avioes-nuclear-theodore-roosevelt-denuncia-contaminacao-e-sua-destituicao-causa-motim/

${ }_{5}^{5}$ https://www.nexojornal.com.br/expresso/2016/04/09/O-mundo-gasta-US-17-trilh\%C3\%A3o-com-for\%C3\%A7as-armadas.-Por-que -this-money-n\% C3\% A3o-has-another-destination

${ }^{6} \mathrm{https}$ ://internacional.estadao.com.br/noticias/geral,10-dos-gastos-militares-acabariam-com-a-pobreza-e-fome-ate-2030,10000024869 
This great role that military spending plays in the US budget is not something restricted to the last few decades, but a recurring practice in that country's economic history. According to Musolf (2004), state intervention, especially in the arms race, allowed the growing demands for state intervention, especially during and after World War II, transforming the US government into the main buyer of the main American industries: The turbulent history of this century has made it clear that the role of the Government as the main buyer of goods and services is not a passing phenomenon. As much as we strive to restore a popular image of the government as something apart from the economy, we would find it difficult to predict a future in which the government was decidedly not the largest individual customer in the economy (MUSOLF, 1968, p. 129 apud GOMES, 2004 ).This fact not only allowed the Pentagon to be the biggest buyer of private goods, but also the central role that this imperialist policy plays in the defense of the great American monopolies in the struggle for the world market. This initiative leaves the class character that the United States has in prioritizing military expenditures to defend its large monopolies, while leaving almost 70 million people without health insurance, who end up being exposed to the spread of COVID 19. However, despite the widespread use of public funds to fund the great war machine that threatens national governments around the world, they propagate the ideology that that country would be the example of free enterprise, not allowing the public fund to finance a public system, while using the state for the purposes of private accumulation.This ideology ends up being the justification for that State not to have a public health system, where the poorest do not have access to any type of medical care. In other words, that state spends almost half of its budget on military activities, while it spends little on public health and ends up exposing the devastating dimension of the pandemic, paralyzing a large part of that economy. The lack of a public health system allows that even before the pandemic that country recorded the loss for 500 thousand families with payment for private health. The pandemic has only deepened this fact. ${ }^{7}$ Furthermore, it is worth remembering that the use of military power in the USA was decisive in the initial phase, when the army and public money were used in the process of indigenous extermination. It played a decisive role in the various wars that led to the expansion of its territory. It is worth remembering that in the two great world wars, this War machine was decisive for its affirmation as a great power. On the other hand, the Cold War from the post-war until the dissolution of the former USSR, led to the affirmation of the Military Industrial Complex and the growing commitment of part of the public money to the supposed task of national defense, which in essence is the defense of interests large monopoly groups.

However, in order to understand the scale of current military spending, we have to see how it happened in the course of capitalist development, especially from the stage marked by the replacement of free competition by monopoly competition after 1870, according to Lenin (1979). In other words, the formation of large monopolies within developed economies and the intensification of capitalist contradictions inaugurate the imperialist phase that gives the arms race a higher degree.Souza (1985) when analyzing the specificity of the post-war period, when the internationalization of capital deepens, highlighting the character of national capital in imperialist countries, which when expanding around the world no longer respected the barrier of their national state "means to affirm that the the capital project is not necessarily identical to the nation's political project, but that of realizing itself using nations "(SOUZA, 1985, p. 73). For him, this fact would influence the characteristics of the national bourgeoisies, since the large corporations operating in the other national states started to have an active role within each country.

In the introduction of neoliberalism in the early 1980s, we had not only the policy of high interest rates that amplified rentism, but the beginning of Reagan's Keynesianism, with the Star Wars project. This moment was marked by a process of attacks on social rights and in the process of privatization of public services, there was an open path to the operation of capitals that were previously in the productive sector, but that were not reinvested due to the fall in the rate of profit.Further on, we had the fall of the Twin Towers, on September 11, 2001, which served to justify a new growth in military spending. Meanwhile, the 2008 crisis, which represented the failure of neoliberalism, eventually led national states to practice a devastating use of public money to save large companies and large banks, in addition to buying a large part of bad bonds, while deepening the situation. austerity policy.It is worth remembering that these countries are also in the so-called G7, a group of wealthier countries, which were highlights in the occurrence of the Social Welfare State until the 1980s, when the neoliberal phase begins. Therefore, these are countries that have higher HDI - Human Development Index and that presuppose greater capacity to face a pandemic situation. Among these countries we have the United Kingdom, which was the great power and dynamic center of the world economy until the early 1920s and the United States, the current power that still holds the world hegemony. They are countries that have a large part of the world GDP and due to the high tax burden and the progressive character it has a high tax revenue. All of this could imply greater capacity to face the pandemic, since they have better infrastructure.

To explain this paradox, we must first remember the resistance that these countries had to establish emergency social isolation. Second, the permission for workers in the industries to continue working. Thirdly, the dismantling of public health systems resulted from the practice of the austerity policy that marked it, the introduction of the Euro and the expansion of the European Union. Fourth, the peculiarity of health in the USA, marked by its private character, where 29 million Americans do not have health insurance, in addition to the more than 30 million who lost their jobs and

${ }^{7}$ See here https://g1.globo.com/globonews/jornal-das-dez/video/nos-eua-por-ano-quase-500-mil-familias-perdem-tudo-para-pagar-dividas-com-hospitais- 8542141.ghtml

${ }^{8}$ In the fall of the Salvador Allende government, in Chile in the early 1970s, we had the participation of American companies. 
health insurance. In addition to these factors we have the so-called illegal, which are outside the scope of any health policy.The inexistence of a Unified Health System in the USA, added to the market character that health has and the great social inequality deepened by the various stages of the capitalist crisis (crisis of the economy. com, crisis of 2008) and by the increase in military spending From 9/11 onwards, they can explain why the greatest economic and military power on the planet became the epicenter of the spread of the pandemic.For that, we need to see how the health system works in the USA. More than that, we need to see how labor relations in that country go. According to a study by the research institute Center for Economics and Policy Research published by BBC News Brasil when comparing the policies of 22 countries with high rates of economic and human development, revealed that the USA is the only one not to offer sick leave. ${ }^{9}$ Thus, due to the absence of sick leave, many workers have to choose between working sick or being without a salary or even losing their job. However, those who do not have health insurance and do not have a public health system, end up avoiding going to the doctor because of the high cost of private health.This fact opens the way for someone who is infected and without access to health to end up transmitting the virus at the same time that their condition may worsen and lead to death. According to the BBC News Brasil newspaper "about $40 \%$ of workers in the service sector and almost $60 \%$ of those who work part time do not have a medical license". According to 2014 CDC (Center for Disease Control and Prevention) data, one in five food service workers reported having worked at least once in the previous year, while they were sick with vomiting or diarrhea. ${ }^{10}$

It is good to remember that even though the Trump administration was informed of the pandemic coming from China, the immediate action was to deny the dimension of the risk to the population, saying that it was a small flu. Before adopting a policy of social isolation as a means of coping, Trump began to spread the idea that the virus was created in a Chinese laboratory as an instrument of Chinese domination policy around the world. However, when that country decided to fight the virus, it faced a health system that excluded a considerable part of the population within an expensive private medicine and profit source of part of the capital immobilized in the sector. The fact is that the occurrence of the pandemic put in check the disaster of the social policies that underpin the health policy in that country.This austerity policy was not exclusive to the USA but was practiced in much of the world, in particular in the European Union, especially in the creation of the EURO. However, its intensification comes from the effects of the 2008 crisis, which increased in Europe since 2010. We know that part of these uncertainties in the pre-pandemic came from attempts to contain the consequences of the 2008 crisis Table 1.

Table 1: Titulos de dfvida interna de governos selecionados (USS bilh6es). Selected government bonds (U \$\$ billion).

\begin{tabular}{|c|c|c|c|c|c|c|c|}
\hline $\begin{array}{c}\text { Paises Selecio- } \\
\text { nados }\end{array}$ & 2005 & 2006 & 2007 & 2008 & 2009 & 2010 & 2011 \\
\hline $\begin{array}{c}\text { Todos os gov- } \\
\text { ernos }\end{array}$ & 22.165 & 24.152 & 26.772 & 29.441 & 34.018 & 38.887 & 41.059 \\
\hline Alcmanha & 1.072 & 1.223 & 1.393 & 1.364 & 1.548 & 1.725 & 1.919 \\
\hline Brasil & 419 & 512 & 694 & 546 & 804 & 949 & 957 \\
\hline Espanha & 407 & 449 & 496 & 449 & 604 & 629 & 737 \\
\hline EUA & 5.918 & 6.23 & 6.593 & 7.895 & 9.472 & 11.154 & 11.606 \\
\hline Frana & 1.08 & 1.209 & 1.405 & 1.437 & 1.693 & 1.662 & 1.941 \\
\hline Grecia & 207 & 244 & 299 & 182 & 181 & 159 & 172 \\
\hline lt $A \backslash$ ia & 1.324 & 1.539 & 1.772 & 1.78 & 1.973 & 1.934 & 2.174 \\
\hline Portugal & 98 & 109 & 124 & 87 & 99 & 115 & 137 \\
\hline Reino Unido & 680 & 835 & 903 & 826 & 1.189 & 1.326 & 1.382 \\
\hline
\end{tabular}

Fonte: BIS. Quarterly revielv. Tabela 16A, v8rios numeros.

•em junho 2011

Source:https://www.scielo.br/scielo.php?script=sci_arttext\&pid=S0103-49792013000100005

Within this, it is important to highlight that that crisis and the deficit intervention of the national states, in the sense of saving large companies and banks, led to a stage of indebtedness in six years that compromised the fiscal capacity of these national states. In this way, each time these countries made fiscal adjustments, in order to pay the growing debts arising from that crisis, they ended up compromising social policies. In the table above we can see that all countries owed a total of US \$ 22 trillion in 2005 and that they owed US \$ 41 trillion in 2011. In other words, the account for countries to cope with the previous crisis was already US \$ 19 trillion. Therefore, the post pandemic will bring a new dimension to the debt of these countries due to the resources directed to large economic groups. This reduction in activity was maintained in the main developed economies in the European Union and Japan, be-

${ }^{9}$ To see https://www.bbc.com/portuguese/internacional-51746841

${ }^{10} \mathrm{To}$ see https://www.bbc.com/portuguese/internacional-51746841 
fore the pandemic, even when central banks practiced monetary policies with interest rates close to zero. In other words, the large expenditures practiced by the national states involved were not sufficient for the resumption of the real economy, serving in large part to resume the gigantic speculation in the stock markets.The European central bank established a policy of austerity for the countries of the European Union that ended up determining a cut in social policies and promoting the privatization of public services with emphasis on health. Thus, even where health remained public, it suffered the consequences of repeated budget cuts. In this way, the reduction of the public deficit to please the financial sector, which rolls part of the public debt came from the fiscal adjustment that attacked social policies. On the other hand, the social impoverishment that has occurred in most countries of the European Union results not only from unemployment and flat wages, but also from the reduction of social rights.However, even with the practice of this policy of physical austerity, we had an amplification of the public debt in these countries. According to Genro (2015) in the third quarter of 2012, that is, at the height of the application of austerity policies, public debt in relation to GDP, in the euro zone, was $90 \%$. In this period, financially considered the moment of extreme gravity for the financial stability of the Eurozone, it had reached $86.6 \%$ in relation to GDP. On the other hand, the total failure of austerity policies was revealed by the maintenance of unemployment among young people, in Spain, of more than $40 \%$ and more than $23 \%$ of the total workforce, with a reduction in the purchasing power of salaried workers. all sectors and, in addition to the devastating crisis in small and medium industrial and service businesses. ${ }^{(1-11)}$

\section{Conclusion}

The motivations of these arms policies made by all countries, but led by the imperialist countries, have their origin in the process of concentration of companies and affirmation of monopolies. This process served to sharpen the contradictions of capitalism. In addition, we had an interpenetration of private agents within the state apparatus, aiming not only to control the hand of the State but also to ensure the interests of large corporations within the national territory, as well as action by these States to dominate States and national economies in the search for new markets. This imperialist policy, in addition to being responsible for an increasing part of the public debt of these countries, ends up compromising social policies that could counteract the effects of the pandemic. However, the beginning of the neoliberal phase in the early 1980s and the dismantling of social policies paved the way for the further destruction of public services and the commercialization of these, also in developed countries. In other words, the states that have experienced the welfare state in the so-called glorious thirty have not been left out of political austerity.The high number of infected and killed in the USA revealsor that the richest, most armed and most indebted nation on the planet has not been able to protect its population from the effects of this pandemic. At the end of May, the USA surpassed
100 thousand dead and one million and six hundred thousand infected people. To get an idea of the scale of these deaths, we need to compare with the number of deaths that occurred in seven decades in the wars in Korea, Vietnam, the Gulf, Afghanistan, and Iraq. This is equivalent to 33 times the number of people who died on $9 / 11 .^{11}$

It is good to remember that Vietnam was the first country to impose a military defeat on the USA. This war ended on August 15, 1973 and caused 58,000 deaths in the USA and 1.1 million Vietnamese, in addition to deepening the US public debt. In the current days in the war against this virus, Vietnam would have registered a second victory over the USA. The US had the first case of COVID 19 infection on January 20,2020, Vietnam had its first record three days later. Even though Vietnam has 95 million inhabitants (2018 data), it did not register death until June 13, 2020, while the USA with 329 million inhabitants on June 13, 2020 reached 116,516 dead. It is worth remembering that this number of deaths by COVID 19 was equal to the number of military deaths in all wars. ${ }^{12}$

That State made the public fund an instrument of the tentacles of large corporations in defending their interests around the world and was not able to allow a public health system that would ensure the confrontation with COVID 19, which has in the dismantling of social policies fertile ground for the high death toll. In addition to the health privatization process in the USA, we have social inequality as a determinant of the highest number of deaths being among blacks, Hispanics and the elderly.The occurrence of this pandemic has given this crisis, in progress, a new level and at the same time a new justification for public spending, without altering the trajectory of privatization of public services, within the policy of fiscal austerity put into practice in most countries. countries. As a result, emergency aid was created in most countries to minimize the social effects on workers, who lost their jobs or who had to remain in social isolation, while releasing trillions of dollars to save companies that were already in crisis, but that have collapsed at the current stage. All of this ends up driving a new stage of indebtedness by the national states that will once again turn to the private agents themselves, who will be helped to buy the new public debt securities.However, for the payment of public debt service, both from the previous and the future phases, these States will resort to fiscal adjustment policies that will mean a new stage of the austerity policy. However, the social inequalities that are typical of the capitalist mode of production are amplified as the dismantling of social policies deepens.Therefore, we can say that among the victims of COVID 19 we have, especially those who are most vulnerable to the absence of social policies, which are compromised by the historical destination of that country, which has always placed military spending 8 and debt service spending as a priority. public, which ensure thethe bourgeoisie to obtain income from public bonds, while it attributed to the market the resolution of social problems.

These facts allow the offer by the private sector of fundamental public services (health and education) to those who can afford

\footnotetext{
${ }^{11}$ To see https://theintercept.com/2020/05/28/coronavirus-eua-100-mil-mortos-trump/

${ }^{12}$ To see https://theintercept.com/2020/05/28/coronavirus-eua-100-mil-mortos-trump/
} 
it, to fully commercialize or the possibility of the private sector to have another source of enrichment, while moving away from the financing of social policies. This fact makes very clear the role of a classic rentier State, which also acts for the sector of capital called productive, which is geared towards the direct extraction of added value, either within its territory or outside it. On the other hand, by abandoning social policies, they allow health and education to become commodities, while using public money to save the large corporations hit by the capitalist crisis since 2008.In the current pandemic to be effectively combated, we need to see why a large part of the world population, regardless of whether it is a developed or underdeveloped country, does not have food, housing (for social isolation) and especially soap and water so that they can wash themselves. hands and a public health system that allows universal access? The answer to this question comes from the capitalist logic of private enrichment and social impoverishment, added to the privatization process of all public services, while prioritizing the payment of the respective public debts and the growing military expenditure. So, if the richest countries are like this, imagine how this tragedy could be amplified even more in the underdeveloped countries?

Much has been said about the economic impact of the pandemic, which is evidently very large, as we do not know when a vaccine or an efficient medication appeared. However, we must not forget that before the beginning of the pandemic, we already had a very delicate economic situation, especially due to the reduction of economic activity in most countries and a high level of indebtedness by the States, as well as private indebtedness. Thus, at each stage of the capitalist crisis, national states use public money to mitigate the effects of the crisis for large capitalist groups, while deepening attacks on the social rights of the majority of the population.

\section{Acknowledgments}

None.

\section{Funding}

None.

\section{Conflicts of Interest}

The authors declare that there is no conflict of interest.

\section{References}

1. Brauchey, Stuart. The Origins of American economic growth. Rio de Janeiro: Record, 1966

2. Brown, Michael B. The Political Economy of Imperialism. Rio de Janeiro: Zahar Editores, 1978.

3. Cook, Fred. The Militaristic State. Rio de Janeiro, Brazilian Civilization, 1965.

4. Genro, Tarsus. On austerity in Europe. Carta capital magazine. São Paulo, 2015.

5. Gomes, José M. Capital Accumulation and Stabilization Plan: a study based on the experience of foreign exchange anchor in Latin America in the 90s / José Menezes Gomes. - São Paulo. USP: Doctoral Thesis, 2004.

6. The wealthiest, most armed and most indebted nations losing the war to a virus. CADTM, Brussels, 2020.

7. Marques, Rosa and Nakatani, Paulo. Crisis, fictitious capital and influx of foreign capital in Brazil. Cad. CRH vol.26 no.67 Salvador Jan./Apr. 2013.

8. Lenin, Vladimir. Imperialism, Upper Stage of Capitalism. Rio de Janeiro, Atlas, 1979

9. Musolf, Lloyd. The State and the Economy: promoting general well-being. São Paulo, Atlas, 1968

10. Souza, Herbert José. Transnational capital and the State. Petrópolis, Vozes, 1985.

11. Woodward, Bob. VEIL: The CIA's Secret Wars. (1981-1987). São Paulo, Best Seller, 1987. 